\title{
Dietary Fluted Pumpkin (Telfairia occidentalis) Improves Reproductive Indices in Male African Catfish (Clarias gariepinus) Broodstock
}

\author{
Adekunle Ayokanmi Dada ${ }^{1} \&$ Victoria Chidinma Ejete-Iroh ${ }^{1}$ \\ ${ }^{1}$ Department of Fisheries and Aquaculture Technology, Federal University of Technology, Akure, Ondo State, \\ Nigeria \\ Correspondence: Adekunle Ayokanmi Dada, Department of Fisheries and aquaculture Technology, Federal \\ University of Technology, Akure, Ondo State, Nigeria. Tel: 234-806-436-483. E-mail: \\ dadaayokanmi@yahoo.com
}

Received: October 19, 2014 Accepted: January 18, 2015 Online Published: June 15, 2015

doi:10.5539/jas.v7n7p228 URL: http://dx.doi.org/10.5539/jas.v7n7p228

\begin{abstract}
The effect of dietary aqueous extract of fluted pumpkin (Telfairia occidentalis) leaf powder on growth and reproductive indices of male catfish, Clarias gariepinus bloodstocks was investigated. Fish fed experimental diets showed significantly improved reproductive indices over the control fish. Significantly higher $(\mathrm{P}<0.05)$ gonadosomatic index was recorded for the fish fed diets of aqueous extract of $T$. occidentalis leaf powder compared to fish fed on control diet. These results revealed that supplement diets with medicinal plant ( $T$. occidentalis) improve gonadosomatic index, and reproductive indices of male $C$. gariepinus broodstocks and this plant has a potential pro-fertility property which can be exploited in fish fingerling production by hatchery operators.
\end{abstract}

Keywords: medicinal plant, milt quality, mudfish, gonadosomatic index, motility

\section{Introduction}

Medicinal plants have been used to enhance fertility and research has confirmed pro-fertility effects in some of the herbs tested in animals and fish. Fluted pumpkin (Telfairia occidentalis) is cultivated in various parts of southern Nigeria and contains Vitamin C, alkaloids and flavonoids which are phytoestrogens with antioxidant properties. T. occidentalis belongs to the family Curcubitaceae and the powder and ethanolic extracts of the leaves has been credited with aphrodisiac or fertility in animal and men (Salman et al., 2008), and may have similar effects in fish. This herb is a known vegetable which improves spermatogenesis in man (Nwangwa et al., 2007). The darkish green leafy vegetable is used as food and herbal medicine. The leaf is also a rich source of protein, oil and minerals but low in crude fiber and also rich source of folic acid, calcium, zinc, potassium, cobalt, copper, iron, vitamins A and K (Ajibade et al., 2006). The leafy vegetables possess anti-microbial and antiviral properties (Nwozo et al., 2004; Olorunfemi et al., 2005).

Many studies have shown that antioxidants can enhance fertility either directly or indirectly and that most plants rich in antioxidants have the tendency to increase sperm count, motility, and enhance sperm morphology (Oluyemi et al., 2007; Adesanya et al., 2007).

Clarias gariepinus are widely introduced around the world. They are found in the South and North Africa. They have also been introduced in Europe, Middle East, and in parts of Asia. C. gariepinus are found in slow flowing lowland streams, shallow lakes, swamps, ponds, ditches, rice paddies and pools left in low spots after rivers have been in flood.

C. gariepinus commands a very good commercial value in Nigerian markets (Ayinla et al., 1994). It has been noted that farming is hardly imaginable without availability of fish seed (Chondar, 1980). Based on a 1992 United Nations Development Project (UNDP) assisted base line study, the total annual fingerlings requirement for Nigeria was 250,000 million while the domestic production stood at 7.2 million (Nwokoye et al., 2007).

T. occidentalis has quite a number of antioxidants such as phenols. There is, therefore a high possibility that $T$. occidentalis can promote fertility. This study was therefore carried out to investigate the effects of the dietary 
supplementation of aqueous extract of $T$. occidentalis leaf powder on the reproductive indices in male $C$. gariepinus broodstocks.

\section{Materials and Methods}

\subsection{Fish, Plant Seeds and Cultured Facilities}

The fresh leaves of Telfairia occidentalis were obtained from a local market in Ado - Ekiti, Ekiti State, Nigeria. The leaves were authenticated in the crop, soil and pest management department, Federal University of Technology, Akure, Nigeria using Odugbemi (2008).

The fresh leaves were air dried and milled to a fine powder using Maulinex electric blender. $500 \mathrm{~g}$ of the powdered leaves were soaked in 1 litre of distilled water for 48 hours, after which it was filtered with a muslin bag. The filtrate was evaporated to dryness in water bath to obtain a solid extract and mixed with a basal feed (40 $\%$ crude protein), comprising standard amounts of fish meal, yellow maize, soy bean meal, blood meal, fish oil, vegetable oil, vitamin premix and starch.

C. gariepinus broodstocks used in the study were collected from Ondo State Agricultural Development Project fish farm, Akure, Ondo State, Nigeria. The broodstocks were transported to research farm of the department of fisheries and aquaculture technology, Federal University of Technology, Akure, Ondo State, Nigeria in plastic bowls. The fish were distributed into outdoor concrete tanks $(1 \times 1 \times 0.6 \mathrm{~m})$, filled with well water and acclimatized for 2 week, during which they were fed the basal diet. The concrete tanks were cleaned weekly, and about $50 \%$ of the culture water was replaced with fresh, well water. Water quality parameters including $\mathrm{O}_{2}, \mathrm{pH}$ and temperature were monitored daily. The average values of these parameters throughout the study were: $\mathrm{O}_{2}=$ $6.35 \pm 0.23 \mathrm{mg} \mathrm{L}^{-1}, \mathrm{pH}=9.7 \pm 0.20$ and temperature $=26.20 \pm 0.26{ }^{\circ} \mathrm{C}$.

\subsection{Experimental Design}

The broodstock $(450-500 \mathrm{~g})$ were stocked into concrete tanks $(1 \times 1 \times 0.6 \mathrm{~m})$ at a density of 6 (six) fish per tank with three replicates per treatment. Four isonitrogenous diets were formulated from practical ingredients (Table 1) where the control basal diet (FPE1) was without aqueous extract of $T$. occidentalis leaf powder and the other diets were supplemented by $0.5,1.0,1.5$ and $2.0 \mathrm{~g}$ aqueous extract of $T$. occidentalis leaf powder $/ 100 \mathrm{~g}$ feed respectively (designated as FPE2, FPE3, FPE4 and FPE5). The experimental diets were formulated to contain almost $40 \%$ crude protein. All dietary ingredients were weighed with a weighing top load balance (Metler Toledo, PB 8001 London). The ingredients were milled to a $3 \mathrm{~mm}$ particle size. Ingredients including vitamin premix and aqueous extract of T. occidentalis leaf powder were thoroughly mixed in a Hobbart A- 2007 pelleting and mixing machine (Hobart Ltd, London, UK) to obtain a homogenous mass, cassava starch was added as a binder. The resultant mash was then pressed without steam through a mixer with $0.9 \mathrm{~mm}$ diameter size. The pellets were dried at ambient temperature $\left(27-30{ }^{\circ} \mathrm{C}\right)$ and stored at $-20^{\circ} \mathrm{C}$ in a refrigerator until the start of the experiment.

The diets were manually fed to the broodstocks at a daily rate of 3\% body weight (BW), twice a day (09:00 and 16:00 h) for 8 weeks. Fish were weighed collectively at biweekly intervals, their average weights were recorded and the daily amount of feed for each tank was readjusted accordingly. 
Table 1. Ingredients in and proximate composition $(\mathrm{g})$ of experimental diets

\begin{tabular}{|c|c|c|c|c|c|}
\hline \multirow{2}{*}{ Ingredients } & \multicolumn{5}{|c|}{ Experimental diets } \\
\hline & FPE1 & FPE2 & FPE3 & FPE4 & FPE5 \\
\hline Fishmeal $(65 \% \mathrm{Cp})$ & 25 & 25 & 25 & 25 & 25 \\
\hline Soybean meal $(45 \% \mathrm{Cp})$ & 40 & 40 & 40 & 40 & 40 \\
\hline Yellow maize & 15 & 15 & 15 & 15 & 15 \\
\hline Blood meal (85\% Cp) & 5 & 5 & 5 & 5 & 5 \\
\hline Fish oil & 4 & 4 & 4 & 4 & 4 \\
\hline Vegetable oil & 6 & 6 & 6 & 6 & 6 \\
\hline Vitamin premix $* *$ & 3 & 3 & 3 & 3 & 3 \\
\hline Binder & 2 & 2 & 2 & 2 & 2 \\
\hline T. occidentalis extract & 0 & 0.5 & 1 & 1.5 & 2 \\
\hline \multicolumn{6}{|c|}{ Proximate composition (\% DM) } \\
\hline Moisture & 4.08 & 5.06 & 5.05 & 4.87 & 5.39 \\
\hline Crude protein & 39.59 & 39.81 & 40.16 & 40.25 & 40.35 \\
\hline Crude lipid & 14.47 & 13.16 & 12.16 & 14.54 & 11.85 \\
\hline Crude fiber & 2.63 & 2.59 & 2.72 & 2.85 & 2.60 \\
\hline Ash & 13.75 & 19.36 & 16.22 & 23.68 & 20.24 \\
\hline NFE & 25.48 & 20.02 & 23.69 & 23.81 & 19.57 \\
\hline
\end{tabular}

Note. Vitamin premix**- An Animal Care ${ }^{(\mathrm{R})}$ Optimix Aqua product for catfish, containing the following per $5 \mathrm{~kg}$ of premix: A = 20,000,000 I.U, D3 = 2,000,000 I.U, E =200,000 mg, K3 = 10,000 mg, B2 = 12,000 mg, B12 = 9 $\mathrm{mg}, \mathrm{B} 1=6,000 \mathrm{mg}, \mathrm{B} 6=11,000 \mathrm{mg}, \mathrm{C}=50,000 \mathrm{mg}$, folic acid $=2,000 \mathrm{mg}$, Niacin $=80,000 \mathrm{mg}$, Calpan $=$ $25,000 \mathrm{mg}$, Biotin $=100 \mathrm{mg}, \mathrm{x}$ Zinc $=30,000 \mathrm{mg}$, Copper $=5,000 \mathrm{mg}$, Iron $=30,000 \mathrm{mg}$, Manganese $=50,000$ $\mathrm{mg}$, Iodine $=1,000 \mathrm{mg}$, Selenium $=100 \mathrm{mg}$, antioxidant $=125,000 \mathrm{mg}$. NFE $=$ Nitrogen free extract $\mathrm{DM}=$ dry matter.

\subsection{Evaluation of Milt Quality}

Milt production and quality were determined at the end of the experiment. 3 fish from respective tanks of the same treatment were randomly collected, ( 9 fish from each treatment in total), were sacrificed and the testes removed. Milt volume was determined by making small incision into the lobes of the testes, the milt squeezed out into a Petri dish. This was measured with plastic syringe in $\mathrm{ml}$.

Motility durations were determined by placing $1 \mu \mathrm{l}$ of milt from each male on a Neubauer hemocytometer, a drop of distilled water was added and covered with a slip. The sperm activity was viewed under Olympus microscopic at 100x magnification to see when all the sperm got stopped (Mims, 1991) while percentage motility from each sample was estimated using light microscope at 400x magnification immediately after addition of $20 \mu \mathrm{l}$ distilled water as an activating solution. During spermatozoa activation, immotile sperm cell (ISC) was counted, and when the activation stopped, whole sperm cells (WSC) were counted (Canyurt et al., 2008). The motile sperm cells (MC) were calculated as:

$$
\begin{gathered}
\mathrm{MC}=\mathrm{WSC}-\mathrm{ISC} \\
\% \mathrm{MC}=\mathrm{MC} / \mathrm{WSC} \times 100
\end{gathered}
$$

Concentration of sperm was determined by counting the number of spermatozoa in sample dilute with distilled water (100x) in a Burker haemocytometer, under 400x magnification (Rainis et al., 2003). Gonado-somatic index (GSI) was computed according to Dahlgren (1979) as:

$$
\text { GSI }=\text { Wet Weight } \text { of Gonad/Wet Weight of Fish } \times 100
$$

Water quality parameters such as temperature, $\mathrm{pH}$ and dissolved oxygen concentration were monitored daily throughout the study period using mercury-in-glass thermometer, pH meter (Hanna H198106 model) and dissolved oxygen meter (JPP- 607 model). 
A one-way analysis of variance (ANOVA) was conducted to test the effect of aqueous extract of T. occidentalis leaf powder gonadosomatic index and reproductive indices of male C. gariepinus broodstocks using SPSS Version 11.0. Least significant difference was used to compare means at $\mathrm{P}<0.05$ (Zar, 1996).

\section{Results}

Data on reproductive performances of the male $C$. gariepinus broodstocks fed supplementary diet of aqueous extract of $T$. occidentalis leaf powder are presented in Table 2. Normal feed intake was observed for the experimental fish. There was significant difference $(\mathrm{P}<0.05)$ in the weight of testes with fish fed diet FPE4 having the highest value while fish fed on diet (FPE2) had the lowest value. This reflects in a corresponding increase in milt volume. Similarly there was significant difference $(P>0.05)$ in gonado-somatic index and milt motility and this reflects in greater improvement in the motility duration of fish fed with diets supplemented with varying inclusion levels of aqueous extract of $T$. occidentalis leaf powder when compared with the control. However, there were significant differences $(p<0.05)$ in milt count across the fish fed different diets supplemented with aqueous extract of $T$. occidentalis leaf powder. The average milt volumes were $1.10 \pm 0.05$, $1.10 \pm 0.05,0.80 \pm 0.05,0.58 \pm 0.08$ and $0.48 \pm 0.03$, respectively for diets FPE5, FPE4, FPE3, FPE2 and FPE1.

The water quality parameters during the experimental period varied as follows: temperature, $22.18-24.50{ }^{\circ} \mathrm{C}$; dissolved oxygen, 6.50-7.06 mg/l; $\mathrm{pH}, 6.94-7.63$ recommended for catfishes.

Table 2. Parameters of $C$. gariepinus broodstocks as affected by the dietary supplementation of aqueous extract of T. occidentalis leaf powder for 56 days (mean \pm S.E.)

\begin{tabular}{llllll}
\hline \multirow{2}{*}{ Parameter } & \multicolumn{5}{l}{ Dietary treatment } \\
\cline { 2 - 6 } & FPE1 & FPE2 & FPE3 & FPE4 & FPE5 \\
\hline Initial fish weight (g) & $486.10(0.90)$ & $485.75(0.25)$ & $487.15(1.95)$ & $487.90(2.20)$ & $486.40(1.10)$ \\
Final fish weight (g) & $493.35(0.25)^{\mathrm{a}}$ & $4.92 .80(1.00)^{\mathrm{a}}$ & $493.65(1.15)^{\mathrm{a}}$ & $494.65(1.05)^{\mathrm{a}}$ & $493.90(1.30)^{\mathrm{a}}$ \\
Weight gain (g) & $7.45(0.65)^{\mathrm{a}}$ & $7.05(1.25)^{\mathrm{a}}$ & $6.50(0.80)^{\mathrm{a}}$ & $6.75(1.15)^{\mathrm{a}}$ & $7.50(0.20)^{\mathrm{a}}$ \\
Weight of testes (g) & $1.84(1.31)^{\mathrm{b}}$ & $0.96(0.35)^{\mathrm{c}}$ & $2.21(1.23)^{\mathrm{a}}$ & $2.76(0.20)^{\mathrm{a}}$ & $1.06(0.22)^{\mathrm{c}}$ \\
Milt volume (ml) & $0.48(0.03)^{\mathrm{a}}$ & $0.58(0.08)^{\mathrm{a}}$ & $0.80(0.05)^{\mathrm{b}}$ & $1.10(0.05)^{\mathrm{c}}$ & $1.10(0.05)^{\mathrm{c}}$ \\
Milt count (×10 $\mathrm{spz} / \mathrm{ml})$ & $123.75(22.25)^{\mathrm{a}}$ & $195.00(7.50)^{\mathrm{a}}$ & $199.25(10.75)^{\mathrm{ab}}$ & $277.50(18.50)^{\mathrm{b}}$ & $246.75(40.25)^{\mathrm{b}}$ \\
Motility duration (sec) & $19.50(6.50)^{\mathrm{a}}$ & $35.00(7.00)^{\mathrm{a}}$ & $33.00(1.00)^{\mathrm{a}}$ & $37.50(4.50)^{\mathrm{a}}$ & $32.50(4.50)^{\mathrm{a}}$ \\
\% motility & $49.53(2.43)^{\mathrm{a}}$ & $52.03(3.33)^{\mathrm{a} b}$ & $58.88(0.38)^{\mathrm{bc}}$ & $68.00(3.55)^{\mathrm{bc}}$ & $60.80(0.25)^{\mathrm{c}}$ \\
GSI (\%) & $0.36(0.13)^{\mathrm{a}}$ & $0.69(0.15)^{\mathrm{a}}$ & $0.67(0.26)^{\mathrm{a}}$ & $0.40(0.08)^{\mathrm{a}}$ & $0.60(0.29)^{\mathrm{a}}$ \\
\hline
\end{tabular}

Note. Mean in a given column with the same letter were not significantly different at $\mathrm{p}<0.05$. Values in parentheses are standard errors of means.

GSI $=$ Gonadosomatic Index $=$ Gonads Weight $(\mathrm{g}) /$ Fish Weight $\times 100$.

\section{Discussion}

The results suggest that dietary aqueous extract of $T$. occidentalis leaf powder at all concentrations improved the reproductive indices and GSI of cultured male African catfish, $C$. gariepinus. These results showed that the aqueous extract of $T$. occidentalis leaf powder treatment enhances reproductive performance, which is reflected in improved milt volume, milt count, motility duration, \% motility and GSI.

High motility durations were obtained in aqueous extract of $T$. occidentalis leaf powder treatments, but the lowest was obtained in control (Table 2). Better milt count values were obtained in the aqueous extract of $T$. occidentalis leaf powder dietary treatments compared to the control and there were significant $(\mathrm{P}>0.05)$ differences among the fish fed the supplementation. Aqueous extract of T. occidentalis leaf powder in diets also promoted reproductive performance in male rat (Salman et al., 2008). Similar results were reported by Sharma et al. (2008) who used the aqueous extract of Anacyclus pyrethrum as a fertility enhancing agent for male rat. Dada (2013) reported that catfish $C$. gariepinus broodstocks fed on diets supplemented by medicinal plants exhibited improved reproductive performance than those fed with the control diet. Similar results were reported for using medicinal plants as fertility-promoting agents for catfish C. gariepinus (Dada \& Ajilore, 2009; Adeparusi et al., 2010; Dada \& Ogunduyile, 2011). 
The improvement in the quality of milt observed in this study could be attributed to the actions of the phytochemical composition of the leaves of T. occidentalis such as flavonoids, steroid. Fasuyi (2006) reported that the chemical composition of the leaves of $T$. occidentalis include proteins, fat, vitamin A, thiamine, riboflavin, nicotinamide, vitamin $\mathrm{C}$ and minerals such as zinc, iron, calcium and magnesium. Adeyeye and Omolayo (2011) also reported that amino acid composition of T. occidentalis includes lysine, histidine, arginine, cysteine methionine and leusine. Some of these active ingredients in T. occidentalis such as flavonoids, steroid have well documented spermatogenic activities. The arginine is a biochemical precursor in the synthesis of putrescine, spermidine and spermine which are essential for sperm motility (Steven, 2000).

It could therefore be concluded that the inclusion of $T$. occidentalis in the diets provided a steady supply of additional nutrients to the fish over the control fish. Zinc promotes growth, sexual maturation and reproduction and there has been evidence associating serum and semen zinc levels with male infertility (Mohan et al., 1997). Carbohydrate-rich $T$. occidentalis could have increased sperm motility and volume by increasing glucose metabolism leading to the production of pyruvate and energy. Pyruvate is known for its preference as substrate essential for the activity and survival of sperm cells (Egbunike et al., 1986). As antioxidants, the flavonoids and vitamins in $T$. occidentalis extract could maintain sperm morphology, sperm survival and sperm function (Nwanna \& Oboh, 2007). The improvement in sperm count could be attributed to antioxidative properties of tannins and vitamin A presence in the leaves (Nkang et al., 2003). According to Sato et al. (2004), vitamin A protects the testis against lipid peroxidation, hence, promotes spermatogenesis and improves structural differentiation of epithelial cells of the epididymis. This explains the increase in milt quality in fish treated with T. occidentalis.

These investigations showed that aqueous extract of $T$. occidentalis leaf powder possess promising profertility property which can be exploited in fish fingerlings production. Results of the studies provide baseline information and established safe limits of using aqueous extract of T. occidentalis leaf powder as profertility agent to increase the fingerlings production in C. gariepinus under hatchery conditions.

\section{Conclusion}

In conclusion, these investigations showed that aqueous extract of $T$. occidentalis leaf powder possess promising profertility property which can be exploited as feed additive to enhance milt quality of the male, C. gariepinus. Results of the studies provide baseline information of using aqueous extract of $T$. occidentalis leaf powder as profertility agent to increase the fingerlings production in C. gariepinus under hatchery conditions.

\section{References}

Adeparusi, E. O., Dada, A. A., \& Alale, O. V. (2010). The effects of medicinal plant (Kigelia africana) on sperm quality of African catfish Clarias gariepinus (Burchell, 1822) Broodstock. Journal of Agricultural Science, 2, 193-199. http://dx.doi.org/10.5539/jas.v2n1p193

Adeyeye, E. I., \& Omolayo, F. O. (2011). Chemical composition and functional properties of leaf protein concentrates of Amaranthus hybridus and Telfairia occidentalis. Agric. Biol. J. N. Am., 2(3), 499-511. http://dx.doi.org/10.5251/abjna.2011.2.3.499.511

Adesanya, O. A., Oluyemi, K. A., Olusori, D. A., Omotuyi, I. O., Okwuonu, C. U., Ukwenya, O. V., \& Adesanya, A. A. (2007). Micromorphometric and stereological effects of ethanolic extracts of Garcinia cambogia seeds on the testes and epididymides of adult Wistar rats. The Internet Journal of Alternative Medicine, 5 , $1-9$.

Ajibade, S. R., Balogun, M. O., Afolabi, O. O., \& Kupolati, M. D. (2006). Sex differences in the biochemical contents of Telfairia occidentalis. Hook f. Journal of Food, Agriculture and Environ, 4, 155-156.

Ayinla, O. A., Kayode, O., Idoniboye-Obu, O. I. E., Oresegun, A., \& Adidu, V. E. (1994). Use of tadpole meal as substitute for fish meal in the diet of H bidorsalis (Geoffrey St Hillarie 1809). J. Aqua. Trop., 9(I), 25-33.

Canyurt, M. A., \& Akhan, S. (2008). Effect of Ascorbic Acid Supplementation on Sperm Quality of Rainbow trout (Onchorynchus mykiss). Turkish Journal of Fisheries and AquaticSciences, 8, 171-175.

Chondar, S. L. (1980). Hypophysation of Indian Major Carps. Satish Book Enterprise Motikatro Agra - 3 (p. 146).

Dada, A. A., \& Ajilore, V. O. (2009). Use of ethanol extracts of Garcinia Kola as fertility enhancer in female catfish Clarias gariepinus broodstock. Interenational Journal of Fisheries and Aquaculture, 1, 1-5.

Dada, A. A., \& Ogunduyile, F. D. (2011). Effects of velvet bean (Mucuna pruriens) on sperm quality of African catfish, Clarias gariepinus (Burchell, 1822) broodstock. Journal of Fisheries and Aquatic Science, 6, 
655-661. http://dx.doi.org/10.3923/jfas.2011.655.661

Dada, A. A. (2013). Dietary sesame improves reproductive performance of male African catfish. World Aquaculture, 44(1), 66-67.

Dahlgren, B. T. (1979). The effects of population density on fecundity and fertility in the guppy, Poecilia reticulata (Paten). J. Fish Biol., 15, 71-91. http://dx.doi.org/10.1111/j.1095-8649.1979.tb03573.x

Egbunike, G. N., Branscheid, W., Pfisterer, J., \& Holtz, W. (1986). Changes in porcine sperm lactate dehydrogenase isoenzymes during sperm maturation. Andrologia, 18, 108-113. http://dx.doi.org/10.1111/j.1439-0272.1986.tb01748.x

Fasuyi, A. O., \& Nonyerem, A. D. (2007). Biochemical, nutritional and haematological implications of Telfairia occidentalis leaf meal as protein supplement in broiler starter diets. Afr. J. Biotechnol., 6(8), 1055-1063.

Mims, S. D. (1991). Evaluation of activator solutions, motility duration and short-term storage of Paddle fish spermatozoa. J. World Aquacult. Soc., 22, 224-229. http://dx.doi.org/10.1111/j.1749-7345.1991.tb00738.x

Mohan, H., Verma, J., Mohan, P., Marwah, S., \& Singh, P. (1997). Interrelationship of zinc levels in serum and semen in oligospermic infertile patients and fertile males. Indian J. Pathol. Microbiol., 40(4), 451-455.

Nkang, A., Omokaro, A., Egbe, A., \& Amanke, G. (2003). Variation of fatty acid proportion during desiccation of Telferia occidentalis seeds harvested at physiological and agronomic maturity. African Journal of Biotechnology, 2(2), 33-39. http://dx.doi.org/10.5897/AJB2003.000-1006

Nwangwa, E. K., Mordi, J., Ebeye, O. A., \& Ojieh, A. E. (2007). Testicular regenerative effects induced by the extracts of Telfairia occidentalis in rats. Caderno de Pesquisa, Serie Biol., 19, 27-35.

Nwanna, E. E., \& Oboh, G. (2007). Antioxidant and hepatoprotective properties of polyphenol extracts from Telfairia occidentalis (Fluted Pumpkin) leaves on acetaminophen induced liver damage. Pak. J. Biol. Sci., 10, 2682-2687. http://dx.doi.org/10.3923/pjbs.2007.2682.2687

Nwokoye, C. O., Nwuba, L. A., \& Eyo, J. E. (2007). Induced propagation of African clariid catfish, Heterobranchus bidorsalis (Geoffrey Saint Hillarie, 1809) using synthetic and homoplastic hormone. African Journal of Biotechnolgy, 6(23), 2687-2693.

Nwozo, S. O., Adaramoye, O. A., \& Ajaiyoba, E. O. (2004). Antidiabetic and hypolipidemic studies of Telfairia occidentalis on alloxan - induced diabetic rats. Nig. J. Nat. Prod. Med., 8, 45-47.

Odugbemi, T. (2008). A textbook of medicinal plants from Nigeria (p. 628).

Olorunfemi, A. E., Arnold, C. I., Emmanuel, O., Nkaima, N., \& Akeem, A. (2005). Hypoglycaemic activity of Telfairia occidentalis in rats. J. Pharm. Biores., 2, 36-42.

Oluyemi, K. A., Jimoh, O. R., Adesanya, O. A., Omotuyi, I. O., Josiah, S. J., \& Oyesola, T. O. (2007). Effects of crude ethanolic extracts of Garcinia cambogia on the reproductive system of male wistar rats. African Journal of Biotechnology, 6, 1236-1238.

Rainis, S., Mylonas, C. C., Kyriakou, Y., \& Divanach, P. (2003). Enhancement of spermiation in European sea bass (Dicentrarchus labrax) at the end of the reproductive season using GnRHa implants. Aquaculture, 19, 873-890. http://dx.doi.org/10.1016/S0044-8486(03)00028-0

Salman, T. M., Olayaki, L. A., \& Oyeyemi, W. A. (2008). Aqueous extract of Telfairia occidentalis leaves reduces blood sugar and increases haematological and reproductive indices in male rats. African Journal of Biotechnology, 7(14), 2299-2303.

Sato, S. F. (2004). Role of fatty acid comparism in the development of metabolic disorders in sucrose induced obese rats. Experimental Biology and Medicine, 229(6), 486-493

Sharma, V., Thakur, M., Chauhan, N. S., \& Dixit, V. K. (2008). Evaluation of the Anabolic, Aphrodisiac reproduction Activity of Anacyclus Pyrethrum DC in Male Rats. Sci. Pharm., 200, 1-13.

Steven, S. (2000). Male infertility: Nutritional and Environmental Consideration. Altern. Med. Rev., 5(1), 28-38.

Viveen, W. J. A. R., Richter, C. J. J., Van Oordt, P. G., Janssen, J. A. L., \& Huisman, E. A. (1986). Practical manual for the culture of the African catfish, Clarias gariepinus. The Hague, Netherlands: Section for Research and Technology, Agricultural University of Wageningen.

Zar, J. H. (1996). Biostatistical analysis (3rd ed., p. 383). Prentice-Hall, Upper Saddle River, New Jersey, US. 


\section{Copyrights}

Copyright for this article is retained by the author(s), with first publication rights granted to the journal.

This is an open-access article distributed under the terms and conditions of the Creative Commons Attribution license (http://creativecommons.org/licenses/by/3.0/). 